\title{
Prevalence and effects of betel nut habit in teenagers
}

\author{
Pratik Rupakar ${ }^{1}$, Jyoti Chawda ${ }^{2, *}$, Sima Odedra ${ }^{3}$, Preeti Lala ${ }^{4}$ \\ ${ }^{1}$ Senior Resident, ${ }^{2}$ Professor and Head, ${ }^{3}$ Assistant Professor, ${ }^{4}$ Pedodontia, ${ }^{1}$ Dept. of Dentistry, ${ }^{2,3}$ Dept. of Oral \& Maxilofacial Pathology, \\ ${ }^{4}$ Dept. of Pedodontics, ${ }^{1}$ Banas Medical College and Research Institute, Palanpur, Gujarat, ${ }^{2,3}$ Government Dental College and Hospital, \\ Ahmedabad, Gujarat, Pacific Dental College and Hospital, Udaipur, Rajasthan, India
}

*Corresponding Author: Jyoti Chawda

Email: researchguide86@gmail.com

\begin{abstract}
Objective: To determine the prevalence and oral effects of betel nut habit among high school in Ahmedabad, Gujarat, India.

Materials and Methods: Study was carried out in 4000 high school children from different zones of Ahmedabad city. Demographic details and clinical data with their socio economic status and chewing habit were recorded.

Results: 912 teenagers had habit of only betel nut chewing of different brands with overall prevalence of $22.8 \%$ and habit was more prevalent in boys as compared to Girls. More than $50 \%$ of boys the habit was initiated at the age of 13 years and habit were common in middle and high class groups of teenagers which were highly significant. Brand III was more favorite in high class group while brand I and brand II were favorite in middle and poor class group of teenagers. Teenagers of south zone where of poor and middle class group resided were more prone to habit. $70 \%$ of them preferred brand I and II while brand III was somewhat equally preferred in other 3 zones which were highly significant. Betel nut chewer shows extrinsic stains and dental decay and Brand III chewer had more deleterious effect on teeth as compared to brand I and II.

Conclusion: This study confirmed the need for a preventive motivation in school children not to initiate betel nut habit and alarm them the potential health risks and effects on aesthetics of this substance by conducting the educational school health programs at regular intervals.
\end{abstract}

Keywords: Age at initiation, Betel nut, High school children, Prevalence, Socio economic status.

\section{Introduction}

Advancement in science and technology has brought enormous development in life. However it has also introduced many problems including health problem. Schools can play a strong role in imparting knowledge and improving the overall health including oral health of young people. Schools provide excellent opportunities for integrating oral health where children are employed to take control over their own health early in their lives. This is particularly crucial when they reach adolescence and they are challenged and exposed to some substances like tobacco and betel nut (Areca nut) which are risk factors of oral cancer. Among them tobacco use is one of the major preventable cause of death worldwide. ${ }^{1}$ Over one-third of tobacco consumed is in smokeless form and usually men are the consumers but now a day it is also prevalent in children, teenagers and women. A youth tobacco surveillance study reported that $68 \%$ of boys and $48 \%$ of girls had their first experience of tobacco before the age of 10 years. ${ }^{1}$ Use of Smokeless tobacco among children is alarming due its genotoxic effect and high addictive nature of nicotine making it difficult to quit. In Gujarat gutkha, a form of smokeless tobacco is more popular which contains mixture of arecanut and tobacco. Arecanut is among the most common addictions following tobacco. It has fibrogenic, genitoxic and carcinogenic effect on oral mucosa. Apart from the carcinogenic potential, arecanut has been shown the typical dependence and its adverse effects include oral leukoplakia, submucous fibrosis and gum diseases., ${ }^{2,3}$ Commercially areca nut is marketed in the form of sweetened areca nut or sweet supari to target school children. ${ }^{4}$ In recent years habit of smokeless tobacco and betel nut is much popular in teenagers. In our preliminary study we could find out that most of the students consume either sweet or plain betel nut. Hence the presence study was concentrated with the objective to determine the prevalence and oral effects of betel nut habit among 13 to 15 years age group of high school children from various socioeconomic strata in Ahmedabad city of Gujarat, India.

\section{Materials and Methods}

During two year period 4000 high school teenagers of 13-15 years age of both the sexes were examined from the ninth, tenth and eleventh standard of private high schools of Ahmedabad city. The city was divided into four zones as north, south, east, and west and 1000 students from each zone were included in the study. They were grouped into three categories considering the socio economic status depending on the monthly income of their parents. Poor class having monthly income less than 1000 rupees, middle class having 1000-5000 rupees and higher class having more than 5000 rupees. Detailed demographic details and clinical data of each student along with their socio economic status were recorded in specially designed history sheet by trained dentists. Details of chewing habit like tobacco or betel nut were noted with age of initiation and duration, frequency and brand of substance used. Their effects on oral mucosal tissue and teeth were recorded. Prior to the study, consent was taken from the concerned school authority and every student who participated in the study. Card of oral health status of each student was sent to their parents through the concerned class teacher. 


\section{Statistical Analysis}

All the data were analyzed with software SPSS version 12.0. The Chi-square test used for qualitative data. All the analysis was done at $5 \%$ level of significance.

\section{Results}

Data were collected using coded proforma which included 4000 high school teenagers to find out the specific chewing habit. There were 2560 boys and 1440 girls. In the present study teenagers were from poor, middle and higher class group. From them 912 teenagers had habit of only betel nut chewing of different brands with overall prevalence of $22.8 \%$ and habit was more prevalent in boys $(99.12 \%)$ as compared to Girls $(0.88 \%)$. They chew $1-2$ sachet of betel nut per day. In more than $50 \%$ of boys the habit was initiated at the age of 13 years and habit was specifically common in middle and high class groups of teenagers which were statistically highly significant. $85 \%$ of teenagers had habit of more than 1 year duration, while only $15 \%$ teenagers had habit of less than one year which is statistically highly significant $(\mathrm{p}<0.0001)$.They preferred three different brands of betel nuts like brand I and brand II which contained sweet betel nut consists of finely cut betel nut, sugar, artificial sweetener, menthol, natural food color and flavors and brand III contained finely cut plain betel nut only. $43 \%$ teenagers had habit of brand III and $60 \%$ of them were of higher class group while brand I and II was nearly equally chewed in $30 \%$ and $27 \%$ teenagers respectively and $70 \%$ of them were of middle class group thus it shows that brand III was more favorite as compared to brand I or II which is statistically highly significant $(\mathrm{p}<0.0001)$ as shown in Table 1 .

On seeing the popularity of specific brand of betel nut used in different zones of Ahmedabad we observed that $46 \%$ teenagers of south zone were more prone to such habit and $70 \%$ of them preferred brand I and II while brand III was somewhat equally preferred in other 3 zones except south zone. Such difference is statistically highly significant $(\mathrm{P}<0.0001)$ which is shown in Table 2.

Betel nut of any brand had effect on teeth either it cause extrinsic stains or tooth decay. There were $54 \%$ teenagers who had brown stains on the teeth and $21 \%$ had tooth decay. Among them brand III chewer showed extrinsic stains in $43 \%$ and dental decay in $48 \%$ teenagers. Thus brand III had more deleterious effect on teeth as compared to brand I and II which is statistically significant $(\mathrm{p}<0.05)$ as shown in Table 3.

Table 1: Correlation of economic status with initiation, duration and brand of betel nut habit

\begin{tabular}{|c|c|c|c|c|c|c|c|c|c|c|c|}
\hline \multirow{2}{*}{\begin{tabular}{|c|} 
Economical \\
Status
\end{tabular}} & \multirow[b]{2}{*}{ Sex } & \multirow{2}{*}{$\begin{array}{c}\text { Total } \\
\text { Students }\end{array}$} & \multirow{2}{*}{$\begin{array}{c}\text { Students } \\
\text { with habit } \\
\text { n } \\
(\%) \\
\end{array}$} & \multicolumn{3}{|c|}{ Starting Age (Years) of Habit } & \multicolumn{2}{|c|}{ Duration of Habit } & \multicolumn{3}{|c|}{ Betel Nut } \\
\hline & & & & $\begin{array}{c}13 \\
n \\
(\%)\end{array}$ & $\begin{array}{c}14 \\
n \\
(\%)\end{array}$ & $\begin{array}{c}15 \\
n \\
(\%) \\
\end{array}$ & $\begin{array}{c}<1 \text { Year } \\
\text { n } \\
(\%)\end{array}$ & $\begin{array}{c}\geq 1 \text { Year } \\
\text { n } \\
(\%)\end{array}$ & \begin{tabular}{|c} 
Brand I \\
n \\
$(\%)$
\end{tabular} & $\begin{array}{c}\text { Brand II } \\
\text { n } \\
(\%)\end{array}$ & $\begin{array}{c}\text { Brand III } \\
\text { n } \\
(\%) \\
\end{array}$ \\
\hline \multirow[t]{2}{*}{ Poor class } & Boy & 64 & $\begin{array}{c}8 \\
(12.5) \\
\end{array}$ & $\begin{array}{c}4 \\
(0.78) \\
\end{array}$ & 0 & $\begin{array}{c}4 \\
(3.45)\end{array}$ & $\begin{array}{c}4 \\
(2.86)\end{array}$ & $\begin{array}{c}4 \\
(0.52)\end{array}$ & $\begin{array}{c}8 \\
(2.99)\end{array}$ & 0 & 0 \\
\hline & Girl & 20 & 0 & 0 & 0 & 0 & 0 & 0 & 0 & 0 & 0 \\
\hline \multirow[t]{2}{*}{\begin{tabular}{|l}
$\begin{array}{l}\text { Middle } \\
\text { class }\end{array}$ \\
\end{tabular}} & Boy & 1392 & $\begin{array}{c}500 \\
(35.92) \\
\end{array}$ & $\begin{array}{c}248 \\
(48.44) \\
\end{array}$ & $\begin{array}{c}176 \\
(61.97) \\
\end{array}$ & $\begin{array}{c}76 \\
(65.52) \\
\end{array}$ & $\begin{array}{c}84 \\
(60) \\
\end{array}$ & $\begin{array}{c}416 \\
(53.89) \\
\end{array}$ & $\begin{array}{c}164 \\
(61.19) \\
\end{array}$ & $\begin{array}{c}180 \\
(72.58) \\
\end{array}$ & $\begin{array}{c}156 \\
(39.39) \\
\end{array}$ \\
\hline & Girl & 924 & $\begin{array}{c}4 \\
(0.43) \\
\end{array}$ & 0 & $\begin{array}{c}4 \\
(1.41)\end{array}$ & 0 & $\begin{array}{c}4 \\
(2.86) \\
\end{array}$ & 0 & 0 & 0 & $\begin{array}{c}4 \\
(1.01)\end{array}$ \\
\hline \multirow[t]{2}{*}{ High class } & Boy & 1104 & $\begin{array}{c}396 \\
(35.87)\end{array}$ & $\begin{array}{c}260 \\
50.78 \\
\end{array}$ & $\begin{array}{c}100 \\
(35.21)\end{array}$ & $\begin{array}{c}36 \\
(31.03) \\
\end{array}$ & $\begin{array}{c}48 \\
(34.29)\end{array}$ & $\begin{array}{c}348 \\
(45.08)\end{array}$ & $\begin{array}{c}96 \\
(35.82)\end{array}$ & $\begin{array}{c}68 \\
(18.65) \\
\end{array}$ & $\begin{array}{c}232 \\
(58.59) \\
\end{array}$ \\
\hline & Girl & 496 & $\begin{array}{c}4 \\
(0.81)\end{array}$ & 0 & $\begin{array}{c}4 \\
(1.41)\end{array}$ & 0 & 0 & $\begin{array}{c}4 \\
(0.52)\end{array}$ & 0 & 0 & $\begin{array}{c}4 \\
(1.01)\end{array}$ \\
\hline \multicolumn{2}{|l|}{ Total } & 4000 & $\begin{array}{c}912 \\
(22.8)\end{array}$ & $\begin{array}{c}512 \\
(56.14) \\
\end{array}$ & $\begin{array}{c}284 \\
(31.14)\end{array}$ & $\begin{array}{c}116 \\
(12.72)\end{array}$ & $\begin{array}{c}140 \\
(15.35)\end{array}$ & $\begin{array}{c}772 \\
(84.65)\end{array}$ & \begin{tabular}{|c|}
268 \\
$(29.39)$
\end{tabular} & $\begin{array}{c}248 \\
(27.19)\end{array}$ & $\begin{array}{c}396 \\
(43.42)\end{array}$ \\
\hline \multicolumn{4}{|c|}{$\mathrm{p}$ value } & \multicolumn{3}{|c|}{$<0.0001^{*}$} & \multicolumn{2}{|c|}{$<0.0001^{*}$} & \multicolumn{3}{|c|}{$<0.0001 *$} \\
\hline
\end{tabular}

*Highly Significant

Table 2: Zone wise distribution of teenagers according to brand of betel nut habit

\begin{tabular}{|c|c|c|c|c|c|}
\hline 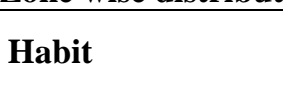 & $\begin{array}{l}\text { North } \\
\text { n }(\%)\end{array}$ & $\begin{array}{l}\text { South } \\
\text { n }(\%)\end{array}$ & $\begin{array}{c}\text { East } \\
\mathrm{n}(\%)\end{array}$ & $\begin{array}{l}\text { West } \\
\text { n }(\%)\end{array}$ & $\begin{array}{l}\text { Total } \\
\text { n }(\%)\end{array}$ \\
\hline Brand I & $\begin{array}{c}12 \\
(4.48)\end{array}$ & $\begin{array}{c}188 \\
(70.15)\end{array}$ & $\begin{array}{c}36 \\
(13.43)\end{array}$ & $\begin{array}{c}32 \\
(11.94)\end{array}$ & 268 \\
\hline Brand II & $\begin{array}{c}16 \\
(6.45) \\
\end{array}$ & $\begin{array}{c}176 \\
(70.97) \\
\end{array}$ & $\begin{array}{c}40 \\
(16.13) \\
\end{array}$ & $\begin{array}{c}16 \\
(6.45) \\
\end{array}$ & 248 \\
\hline Brand III & $\begin{array}{c}108 \\
(27.27)\end{array}$ & $\begin{array}{c}56 \\
(14.14) \\
\end{array}$ & $\begin{array}{c}112 \\
(28.28) \\
\end{array}$ & $\begin{array}{c}120 \\
(30.31)\end{array}$ & 396 \\
\hline Total & $\begin{array}{c}136 \\
(14.91) \\
\end{array}$ & $\begin{array}{c}420 \\
(46.05)\end{array}$ & $\begin{array}{c}188 \\
(20.62) \\
\end{array}$ & $\begin{array}{c}168 \\
(18.42)\end{array}$ & 912 \\
\hline $\mathrm{P}$ value & & $<0.0001 *$ & & & \\
\hline
\end{tabular}


*Highly Significant

Table 3: Effects of different brands of betel nut on teeth

\begin{tabular}{|l|c|c|c|}
\hline Betel Nut & $\begin{array}{c}\text { Extrinsic Stains } \\
\mathbf{n}(\boldsymbol{\%})\end{array}$ & $\begin{array}{c}\text { Tooth Decay } \\
\mathbf{n}(\boldsymbol{\%})\end{array}$ & Total \\
\cline { 2 - 5 } & $\begin{array}{c}144 \\
\text { Brand I }\end{array}$ & $\begin{array}{c}36 \\
(18.37)\end{array}$ & 268 \\
\cline { 2 - 4 } & 140 & 64 \\
Brand II & $(28)$ & $(32.65)$ & 396 \\
\hline & $\begin{array}{c}216 \\
(43.2)\end{array}$ & $\begin{array}{c}196 \\
(21.49)\end{array}$ & 912 \\
\hline
\end{tabular}

* Significant

\section{Discussion}

Betel nut chewing is considered as benign and socially accepted habit among most Indian. ${ }^{2}$ It usually starts at teen age so high school children are regular chewer of betel nut and then they continue the habit into their adult life. It is a major public health problem and long term use of such substance cause oral submucous fibrosis, a potentially malignant condition of oral cavity and also has a significantly increased risk of oral and oropharynx cancer. ${ }^{5,6}$ Apart from this, betel nut affects the teeth which can lead to extrinsic stains or decay of teeth or dental attrition. ${ }^{3}$ Medical effects of betel nut chewing range from habitual to addiction and psychosis.

Chewing betel nut on habitual basis is known health hazard. Large scale epidemiologic studies have shown that in absence of tobacco or lime betel nut have potentially harmful effects on oral soft and hard tissues. ${ }^{3}$ Report of IARC showed that areca nut is carcinogenic to human. ${ }^{5}$ Chemically areca nut consists of arecoline, arecaidine, guavacoline and guavacine. From them Arecoline, the major alkaloid have a genotoxic effect and other substances of areca nut make it more genotoxic. ${ }^{7}$ Along with areca alkaloids and its hydrolysed product arecaidine have the role in stimulating fibrosis. ${ }^{8}$

In the present study 4000 teenagers were included from the Ahmedabad city of Gujarat, India and the detail demographic data showed that they were of different socio economic strata. In this study boys rather than girls were significantly more prone to betel nut habit which is in favors of findings of other studies ${ }^{9-11}$ but most unexpected and contradictory to us the findings from the study of Sarita et al (2011) shows girls were found to initiate habits significantly earlier than boys whereas findings from global youth tobacco survey showed lack of gender difference. ${ }^{12,13}$ In the present study the risk period of engaging habit was 13 to 15 years which was quite correlating to finding of Nitin et al (2010) and somewhat late than reported by Eric et al (2005), and Raj et al $(2011)^{2,6,14}$ In present study frequency of usage of betel nut decreases with the age but contradictory finding is reported by Farrand et al (2001) and Yang MS et al (1996) and they noted that the frequency of usage increases with the age. ${ }^{10,15} \mathrm{We}$ found that teenagers from poor and middle class groups preferred brand I and II which consist of only sweet betel nut while majority of teenagers of higher class group chewed brand III which consist of plan betel nut. Most of them chewed 1-2 sachets per day and the prevalence of betel nut chewing was $22.8 \%$ with more than 1 year of duration. We noticed that they indulged with the habit from their friends as well as some of them feel better as it is chewed for longer period. Also it indicates that this habit was significantly prevalent among middle and higher class group of teenagers and possible explanation may be that these groups of teenagers get pocket money from their parents easily so they can indulge in such habit to refresh themselves but they are unaware of its hazards.

The findings of zone wise distribution revealed that teenagers of south zone predominantly affected by sweet betel nut habit of brand I and II who were of poor and middle class group of industrial worker that might be due to lack of parental knowledge and guidance of such hazardous substance while from remaining other three zones brand III was preferred by the higher class group of teenagers but they were comparatively least affected which may be due to some kind of family restriction to use such substance. We had seen that there was $22.8 \%$ prevalence of betel nut chewing in teenagers but oral sumucous fibrosis was not seen in any of them that might be due to shorter duration of habit i.e. only 3 years or less with use of only 1-2 sachet per day.

There were $50 \%$ teenagers who had stained teeth and $21 \%$ had tooth decay which is also reported in study of Nitin et al. (2010). 2,9 Brand III users were significantly more affected by stains and decay of teeth than brand I and II which may be due to difference in their ingredients. Content of the brand I and II exaggerate the salivary flow that can favors the cleansing of teeth whereas brand III is made up of only plain betel nut which sticks to the teeth instead of cleansing and thus affects them.

In this study we observed that girls are more conscious for their oral health hence they refrained from habit which can deteriorate their esthetics by causing stains on teeth. While middle and higher class groups of boys are more prone to such habit to show their well-being or may be to relieve the mental stress cause due to education burden at the cost of their oral health. Betel nut habit starts in early 
age of life which increases the risk of oral cancer. Therefore habit and alarm them the potential health risks and effects on aesthetics by conducting the educational school health programs at regular intervals. Special efforts are needed for cessation of such dangerous habit through training programs for teachers and parents as well as through media to effectively inform and educate the school children.

\section{Acknowledgements}

Authors would like to thank Mr. B C Lakkad, Ex. Deputy Director, National Institute of Occupational Health (NIOH), Ahmedabad, Gujarat, India.

\section{Conflict of Interest: None.}

\section{References}

1. Muttappallymyalil J, Sreedharan J, Divakaran B. Smokeless tobacco consumption among school children. Indian J Cancer. 2010;47:19-23.

2. Nitin Joseph, Nagaraj K, Shashidhar Kotian M. Arecanut and tobacco use among school children in a village in South IndiaA cross sectional study. Aust Med J. 2010;3:299-210.

3. C.R. Trivedy, G. Craig, S.Warnakulasuriya. The oral health consequences of chewing areca nut. Addiction Biology 2002; 7:115-125.

4. Ashok Khandelwal, Vishal Khandelwal, Mainak Saha, Sushma Khandelwal, Sai Prasad, Suparana Saha. Prevalence of areca nut chewing in the middle school going children of Indore, India. Contemporary Clinical Dentistry. 2012;3:155-157.

5. Betel-quid and areca-nut chewing and some areca nut derived nitrosamines. IARC Monograph on the Evaluation of Carcinogenic Risk of Chemicals to Humans. 2004;85.

6. Eric Oakley, L. Demaine, Saman Warnakulasuriya. Areca (betel) nut chewing habit among high-school children in the commonwealth of the Northern Mariana Islands (Micronesia) Bulletin of the World Health Organization. 2005;83(9):656660. preventive motivation in school children not to initiate such

7. Dave BJ, Trivedi AH, Adhvaryu SG. In vitro genotoxic effects of areca nut extract and arecoline. J Cancer Res Clin Oncol. 1992;118(4):283-288.

8. G.A. Load, C.K. Lim, S. Warnakulasuriya, T.J. Peters. Chemical and analytical aspects of areca nut. Addiction Biology 2002; 7: 99-102.

9. Robert O. Greer, Todd C. Poulson. Oral tissue alterations associated with the use of smokeless tobacco by teen-agers. Oral Surg, Oral Med, Oral Pathol. 1983;56(3):275-284.

10. Yang MS, Su IH, Wen JK, Ko YC. Prevalence and related risk factors of betel quid chewing by adolescent students in southern Taiwan. J Oral Pathol Med. 1996;25:69-71.

11. CT Lu, SJ Lan, CC Hsieh, MJ Yang, YC Ko, CC Tsai, et al. Prevalence and characteristics of areca nut chewers among junior high school students in Changhua country, Taiwan. Community Dent Oral Epidemiol. 1993;21:370-373.

12. Sarita Sardana and Raj Narain. Tobacco and Non tobacco abuse among school children in Noida, India. Indian Pediatr. 2011;48(1):77-78

13. Global Youth Tobacco Survey Collaborating Group. Differences in worldwide tobacco use by gender: findings from the Global Youth Tobacco Survey. J School Health. 2003;73:207-215.

14. Raj Narain, Sarita Sardana, Sanjay Gupta, Ashok Sehgal. Age at initiation \& prevalence of tobacco use among school children in Noida, India: A cross-sectional questionnaire based survey. Indian J Med Res. 2011;133:300-307.

15. P. Farrand, R.M. Rowe, A. Johnston, H.Murdoch. Prevalence, age of onset and demographic relationship of different area nut habits amongst children in Tower Hamlets, London. Br Dent $J$. 2001;190(3):150-154.

How to cite this article: Rupakar P, Chawda J, Odedra S, Lala P. Prevalence and effects of betel nut habit in teenagers. J Oral Med, Oral Surg, Oral Pathol, Oral Radiol. 2018;4(4):178-181. 